\title{
PIP Gene
}

National Cancer Institute

\section{Source}

National Cancer Institute. PIP Gene. NCI Thesaurus. Code C92508.

This gene plays a role in ligand binding. 